УДК 371.3(378)

Дмитро Вітер, доктор філософських наук, старший науковий співробітник Національний університет оборони України імені Івана Черняховського ORCID ID 0000-0002-7330-1280

Олег Мітягін, кандидат історичних наук Національний університет оборони України імені Івана Черняховського ORCID ID 0000-0003-1941-3561

DOI: $10.33099 / 2617-1775 / 2020-01 / 81-90$

\title{
ПРОФЕСІОНАЛІЗАЦІЯ ВІЙСЬКОВОЇ ОСВІТИ В УКРАЇНІ: ГОЛОВНІ НАПРЯМКИ, ЗМІСТ ТА ПЕРСПЕКТИВИ
}

Досліджено питання розвитку професійної військової освіти в Украӥні, визначено основні напрямки, зміст та перспективи ії формування з урахуванням досвіду країн-членів НАТО у иій сфері. Запропоновано концептуальну модель формування обрису офічера майбутнього та структуру курсової професійної підготовки офіиерів на тактичному, оперативному та стратегічному рівнях.

Ключові слова: військова освіта; курсова підготовка; лідерські курси; НАТО; обрис офіиера; офіиерські кадри; підготовка військових фахівців; професійна військова освіта.

Постановка проблеми. Основною тенденцією розвитку системи військової освіти у країнах-членах НАТО є іiі професіоналізація 3 метою підвищення ефективності підготовки офіцерів та військових фахівців. Досвід країн-членів НАТО свідчить про те, що система підготовки офіцерів та військових фахівців для сил безпеки і оборони має такі особливості: чітко виражена спеціалізація, інтенсивність та короткостроковість навчального процесу. Водночас для підготовки офіцерських кадрів в якості пріоритетів визначається практичне спрямування навчання, що зорієнтовано на вирішення конкретних практичних завдань; вивчення важливих для безпеки держави предметів в області міжнародних відносин; якісний відбір кадрів для сил безпеки і оборони. Кардинальні зміни структури системи військової освіти, які характерні для більшості країн-членів НАТО, мають на меті побудову сучасної моделі професійної військової освіти, що забезпечує підготовку офіцерів, здатних на практиці вирішувати складні завдання, пов'язані з усім комплексом проблем, що виникають в оперативному середовищі. Ураховуючи що реформа системи національної безпеки і оборони України передбачає інтенсифікацію якісних змін у сфері підготовки офіцерських кадрів для Збройних Сил 3 урахуванням особливостей курсу держави на євроатлантичну інтеграцію, питання професіоналізації військової освіти в Україні $є$ актуальним та потребує адекватного вирішення. В останньому випадку йдеться про необхідність оптимального поєднання набутого в Україні досвіту підготовки офіцерів та стандартів НАТО у системі вищої військової освіти, яка залишається одним 3 пріоритетних факторів розвитку систем національної безпеки і оборони. 
Метою статі є визначення основних напрямків, змісту та перспектив формування системи професійної військової освіти в Україні з урахуванням досвіду країн-членів НАТО у цій сфері.

Методи дослідження. У статті використано систему загальнонаукових i спеціальних методів теоретичного та емпіричного дослідження (систематизація та узагальнення, логічно-порівняльний методи, системний підхід, метод моделювання).

Виклад основного матеріалу. Важливим здобутком розвитку системи військової освіти України є поєднання двох основних складових - освітньої та професійної. Інституціональне забезпечення цієї системи дозволяє здійснити перехід до професіоналізації військової освіти без втрати переваг ані освітньої, ані професійної складової, що забезпечує збереження інтегрального характеру підготовки офіцерів з урахуванням сучасних вимог до іiі характеру і змісту. Водночас Україна потребує вдосконалення професійної складової підготовки офіцерів, що може бути виконано в межах розвитку професійної військової освіти.

Професійна військова освіта (ПВО) $є$ формою військової освіти, яка грунтується на міждисциплінарному підході й являє собою постійний процес підготовки офіцерів на основі отримання ними стійкої сукупності знань, вмінь та навичок з у сфері науки та мистецтва війни $[9 ; 13]$. Крім цього, ПВО характеризується як визнаний комплекс цілей, політик і процедур, які підтримують освітні вимоги до офіцерів [7;8]. Ураховуючи зміст ПВО, його сутність та основні характеристики, які забезпечують планомірний розвиток системи підготовки офіцерів у країнах-членах НАТО, можна зазначити, що професіоналізація військової освіти в Україні передбачає інтеграцію органів управління військовою освітою, мережі закладів військової освіти, діючих стандартів освітньої діяльності і стандартів освіти (професійний стандарт), рівнів і ступенів кваліфікації освіти (галузева рамка кваліфікацій), законодавчої та нормативно-правової бази тощо в єдиний комплекс професійної підготовки офіцерів.

Такий комплекс складається 3 декількох невід'ємних від процесу підготовки офіцера компонентів: розуміння особливостей професії військового, професійного розвитку, загальних професійних компетентностей, функціональних професійних компетентностей, індивідуальної та спільної підготовки, формування обрису офіцера майбутнього. Кожен компонент має місце в концептуалізації ПВО і визначає базові умови розвитку іï структури у зв'язку із конкретними пріоритетами та орієнтирами професійного зростання офіцера. Так, професія військового характеризується наявністю важливих специфічних функціоналів та особливостей рольової взаємодії, які відрізняють цю професію від інших. Серед основних, базових функціоналів виділяються: прихильність військовій етиці, командні (лідерські) якості, приналежність військовій професії, висока громадянська та патріотична позиція. Ці функціонали реалізуються в таких характеристиках офіцера, як обов'язок, честь, відданість, готовність служіння державі, компетентність, колективізм, організаторські здібності. Відповідність офіцера наведеним характеристикам 
визначає ядро професійної армії. Відповідно отримання професії військового пов'язане з набуттям необхідних загальних професійних компетентностей, тобто динамічної сукупності загальних знань, умінь та навичок, якими мають володіти всі офіцери, незалежно від роду військ чи сфери застосування, й які формуються на всіх рівнях професійної військової освіти, а також функціональних професійних компетентностей, тобто динамічної сукупності знань, умінь і навичок, обов'язкових для офіцера певного роду військ чи структурного підрозділу, які залежать від тактики, певного виду зброї та обладнання та/або специфіки застосування структурного підрозділу, специфіки функціональної зони. Ці компетентності отримуються офіцерами, як правило, перед призначенням осіб на посаду структурного підрозділу.

Набуття необхідного комплексу компетентностей, що безпосередньо розкривають зміст професії та характеризують професійний рівень підготовки офіцера, здійснюється в процесі професійного розвитку (планомірний, прогресивний, такий, що здійснюється упродовж кар'єри офіцера процес освіти, саморозвитку та набуття практичних знань, навичок, вмінь), індивідуальної (розвиток вмінь і знань, які необхідні для виконання конкретних посадових обов'язків та завдань на основі вивчення і засвоєння способів реагування на передбачені ситуації) та спільної підготовки (воєнна підготовка, що грунтується на спільній доктрині або спільних тактиках, методах i процедурах, використовуваних для підготовки офіцерів командного складу, які проходять службу в об'єднаних штабах, спільних силах реагування на оперативному та стратегічному рівні), які є основними складовими процесу професійної підготовки в межах системи ПВО.

Узагальнення досвіду країн-членів НАТО дає можливість вказати на наступні вимоги до професійної підготовки офіцерів [4; 5; 6]:

- формування здатності керувати військами (силами) в бою (операції), навчанням, вихованням, психологічною підготовкою особового складу в мирний і воєнний час;

- розвиток критичного і стратегічного мислення, прийняття рішень в умовах невизначеності та високого ступеня ризику;

- забезпечення адаптивності до змін організаційної структури і технологій;

- формування здатності до спільного планування, розуміння і здійснення співпраці зі структурами НАТО на оперативному та стратегічному рівні;

- набуття вмінь та навичок з експлуатації і застосування найскладніших систем озброєння та військової техніки;

- формування здатності ефективно діяти при виконанні завдань, які виникають під час здійснення міжнародних антитерористичних і миротворчих операцій, участі в ліквідації локальних воєнних конфліктів тощо;

- забезпечення суворого добору кандидатів для навчання у військових навчальних закладах й розвиток активно діючої системи відсіву нездатних до процесу навчання. 
Наведені вимоги є основою формування обрису офіцера майбутнього, який набуває визначальних ознак з огляду на розвиток системи професійної військової освіти, про що свідчить досвід країн-членів НАТО [2; 11; 12], які орієнтуються на розуміння того, що бачення офіцера майбутнього, як визначник системи військової освіти та професіоналізації, спрямоване на розвиток особистості офіцера, здатного стратегічно й критично мислити, розробляти плани ведення спільних бойових дій, творчо реалізовувати набуті знання та навички 3 оперативного мистецтва та застосування воєнного потенціалу держави $[1 ; 3 ; 10]$. Реалізація основних положень та принципів, що формують обрис офіцера майбутнього, має здійснюватись у системі ПВО, яка орієнтується на формування та розвиток офіцерів-лідерів в інтелектуальній сфері, забезпечення досягнення ними високого рівня професіоналізму в теорії та практиці ведення бойових дій (операцій), одночасно створюючи умови для поглиблення знань 3 воєнної історії у поєднанні 3 вивченням передових методів, технологій та способів ведення збройної боротьби, досягнення сумісності при проведенні міжнародних операцій, а також здібностей розробляти пропозиції з питань оборони та застосування збройних сил на рівні вищого політичного керівництва держави. Таким чином, система ПВО в якості результату потребує орієнтації на формування у офіцера стійкої сукупності знань, навичок та вмінь, які забезпечують високий рівень професіоналізму та лідерських якостей, що у сукупності проявляється як обрис офіцера.

Основними елементами обрису офіцера майбутнього є (у розподілі за освітньою, професійною складовими та загальними компетентностями):

Тактичний рівень підготовки:

- критичне мислення, знання соціальних процесів, управління в інформаційному середовищі, принципи збройної боротьби, міжнародне гуманітарне право;

- ініціативність, відповідальність, комунікативність, психологічна адаптивність, саморозвиток;

- критичний аналіз, вирішення малоструктурованих завдань, впровадження стандартів НАТО, управління підрозділом, стресостійкість.

Оперативний рівень підготовки:

- системний аналіз, історія війн та оперативне мистецтво, Case-study, управління проектами, військове право, стандарти НАТО;

- когнітивність, комплексність та динамічність, структури, політики та процеси, планування спільних операцій, військова етика;

- системне, аналітичне мислення, операційна сумісність, управління ризиком, лідерство, планування оперативного середовища.

Стратегічний рівень підготовки:

- управління ресурсами, стратегічний менеджмент, воєнна доктрина, національна і колективна безпека, оперативне мистецтво;

- управління соціальними процесами, прийняття рішень 3 питань безпеки оперативного середовища, проведення спільних операцій, розвиток глобального оперативного середовища; 
- стратегічне лідерство, оборонне планування, стратегічне мислення, управління змінами, рекомендації з питань міжнародної та національної безпеки, розвиток Збройних Сил.

Зазначені елементи обрису офіцера майбутнього відображують необхідний рівень освітньої та професійної підготовки, якого офіцер має прагнути. Можливість досягнення того чи іншого рівня професіоналізму, відображеного в обрисі, є невід'ємною від високих особистісних якостей (світогляд, менталітет, культура, інтелект тощо), морально-етичних норм та ціннісних орієнтацій (патріотизм, відданість, вірність тощо), які приймає та поділяє офіцер. Розвиток системи ПВО в Україні може бути представлений 3 урахуванням вимог до формування обрису офіцера майбутнього в рамках відповідної моделі (Рис. 1), яка $є$ концептуально-методологічною основою професіоналізації військової освіти, визначаючи головні напрями, зміст та результати професійної підготовки на всіх рівнях.

Згідно наведеної моделі в основу вибору оптимального варіанта професіоналізації військової освіти доцільно покласти принцип поєднання двох основних складових:

- освітньої (фундаментальна військова освіта, що проводиться у ВВНЗ, ВНП ЗВО з підготовки осіб на посади офіцерського складу на певному рівні вищої освіти $з$ присудженням їм відповідного ступеня вищої освіти і видачею після успішного завершення навчання диплома державного зразка);

- професійної (курсова підготовка офіцерів та військових фахівців, що проводиться у процесі виконання ними службових функцій на посадах у військах (силах) на основі лідерських курсах перед призначенням офіцерів на вищі посади 3 видачею після успішного завершення навчання відповідного відомчого сертифікату).

Професіоналізація військової освіти

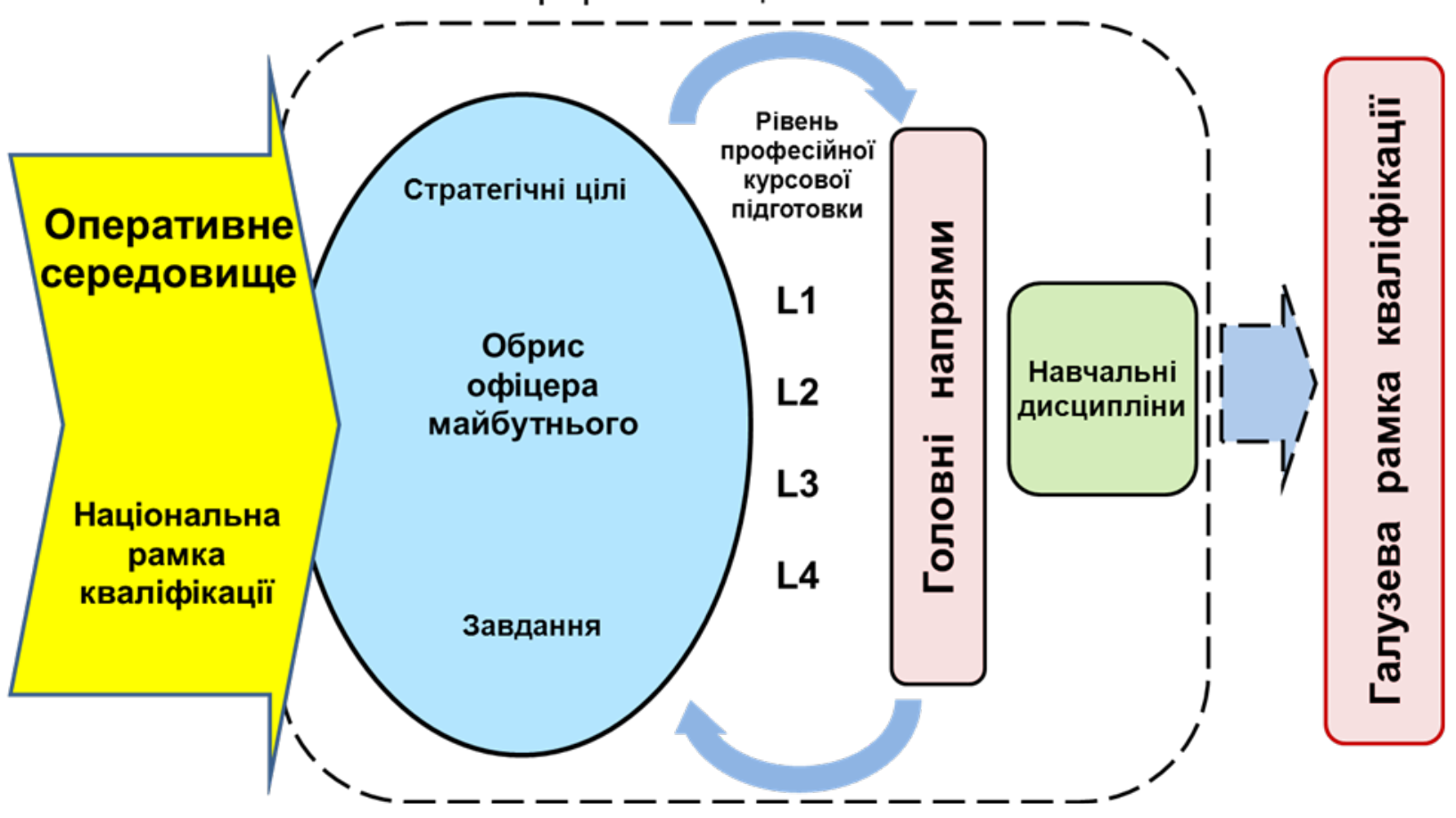


Рис. 1. Концептуальна модель професіоналізації військової освіти

3 точки зору об'єктивації в межах процесу професійної військової освіти та підготовки офіцерів наведений принцип має обов'язково враховувати зміни в оперативному середовищі у поєднанні з основними вимогами, що закріплені у вітчизняній нормативно-правовій базі, яка регулює питання військової освіти. Це має забезпечити узгодження стратегічних цілей та завдань, які формують зміст професійної військової освіти та підготовки офіцерів, та визначення головних напрямів іiї розвитку, зорієнтованих на результат.

У свою чергу, професіоналізація військової освіти, грунтуючись на досвіді країн-членів НАТО, передбачає запровадження чотирьохрівневої системи професійної підготовки, рівні курсової (лідерської) підготовки якої мають функціональну відповідність до тактичного (L1), оперативного (L2, L3) і стратегічного (L4) рівнів військової освіти:

L 1 - курс базової підготовки офіцерів (підготовка на посади не вище командира роти (батареї);

L 2 - курс підготовки на посади батальйонної ланки;

L 3 - курс підготовки на посади бригадної ланки;

L 4 - курс підготовки вищого керівного складу та офіцерів Генерального штабу.

Лідерський курс (L-1) є завершальним етапом підготовки офіцерів першого рівня і проводиться 3 метою здобуття військово-облікової спеціальності. Офіцери, які пройшли курс, отримують відомчий документ і призначаються на посаду відповідно до отриманої спеціальності (рід військ). Цей рівень підготовки призначений для виконання майбутніми офіцерами обов'язків за посадою не вище командира роти (батареї, відповідного рівня кар'єри в авіації, військово-морської частини) в штабі, навчальному закладі чи адміністративному підрозділі.

Метою лідерського курсу (L-2) є підготовка офіцерів до планування i виконання бойових дій на рівні батальйону. Навчання фокусується на процесі прийняття рішень, управлінні діями підрозділів батальйону та організації взаємодії із приданими йому підрозділами з урахуванням досвіду країн-членів НАТО. Офіцери, які пройшли курс, отримують відомчий документ i призначаються на посаду відповідно до їх спеціальності.

Лідерський курс (L-3) призначений для курсової підготовки офіцерів на посади бригадної ланки. Метою підготовки $\epsilon$ вдосконалення навичок об'єднаного планування в контексті оперативного мистецтва, розуміння i здатності виконання вимог НАТО, підготовка офіцерів до і виконання бойових дій на рівні бригади (полку). Навчання фокусується на військовому процесі прийняття рішень, управлінні діями підрозділів бригадного рівня та організації взаємодії із приданими йому підрозділами з урахуванням досвіду країн-членів НАТО. Офіцери, які пройшли курс, отримують відомчий документ i призначаються на посаду відповідно до отриманої спеціальності.

Лідерський курс (L-4) призначений для підготовки вищого керівного складу та офіцерів Генерального штабу. Метою курсу є підготовка офіцерів для 
національних та/або міжнародних організацій (штабів, управлінь) стратегічного рівня. Протягом навчання увага зосереджується на міжнародних відносинах, економічних заходах та збройних засобах стримування. Навчання відбувається виключно у НУОУ та навчальних закладах НАТО.

Нормативною частиною запропонованої курсової підготовки є зміст іiі головних напрямів на відповідних рівнях (Табл. 1).

Таблиця 1

Зміст підготовки військових фахівців на лідерських курсах (варіант)

\begin{tabular}{|c|c|c|c|}
\hline \multicolumn{4}{|c|}{ Рівень підготовки } \\
\hline L1 & L2 & L3 & L4 \\
\hline \multicolumn{4}{|c|}{ Головні напрямки } \\
\hline $\begin{array}{c}\text { Застосування за } \\
\text { призначенням }\end{array}$ & Оперативна сумісність & $\begin{array}{c}\text { Лідерство і оперативне } \\
\text { мистецтво }\end{array}$ & Стратегічне лідерство \\
\hline \multicolumn{4}{|c|}{ Зміст } \\
\hline $\begin{array}{l}\text { Принципи } \\
\text { боротьби }\end{array}$ & $\begin{array}{l}\text { Розгортання та } \\
\text { застосування сил } \mathrm{i} \\
\text { засобів на тактичному } \\
\text { рівні }\end{array}$ & $\begin{array}{lr}\text { Розгортання } & \text { та } \\
\text { застосування сил } & \text { 1 } \\
\text { засобів } & \text { на } \\
\text { оперативному рівні } & \end{array}$ & $\begin{array}{l}\text { Оборонне планування та } \\
\text { управління ризиками }\end{array}$ \\
\hline $\begin{array}{ll}\text { Принципи } & \text { ведення } \\
\text { спільних дій } & \end{array}$ & $\begin{array}{l}\text { Сумісність у складі } \\
\text { сил } \\
\text { багатонаціональних } \\
\text { формувань }\end{array}$ & $\begin{array}{lr}\text { Планування } \\
\text { проведення } \\
\text { операцій }\end{array}$ & $\begin{array}{l}\text { Міжнародна співпраця у } \\
\text { військовій сфері }\end{array}$ \\
\hline Стандарти НАТО & $\begin{array}{l}\text { Оперативна підготовка } \\
\text { штабів }\end{array}$ & $\begin{array}{l}\text { Інтегрована система } \\
\text { управління силами і } \\
\text { засобами }\end{array}$ & $\begin{array}{l}\text { Стратегія національної } \\
\text { безпеки і оборони }\end{array}$ \\
\hline $\begin{array}{lc}\text { Потреби } & \text { національної } \\
\text { безпеки } & \text { i } \\
\text { держаборони }\end{array}$ & $\begin{array}{lr}\text { Тенденції } & \text { розвитку } \\
\text { міжнародних відносин }\end{array}$ & $\begin{array}{l}\text { Пріоритети зовнішньої } \\
\text { та внутрішньої } \\
\text { політики держави }\end{array}$ & $\begin{array}{l}\text { Загрози та } \\
\text { оперативного } \\
\text { середовища }\end{array}$ \\
\hline $\begin{array}{l}\text { Підготовка особового } \\
\text { складу }\end{array}$ & $\begin{array}{l}\text { Адміністративне } \\
\text { управління }\end{array}$ & $\begin{array}{l}\text { Оперативне } \\
\text { управління }\end{array}$ & $\begin{array}{l}\text { Воєнно-політичне } \\
\text { державне управління }\end{array}$ \\
\hline
\end{tabular}

Наведене диктує такі основні вимоги до системи ПВО: чіткість, конкретно-зорієнтованість на цілі, актуальність та адаптивність до змін сучасної тактики і стратегії, способів та методів ведення збройної боротьби, динаміки змін оперативної обстановки та оперативного середовища.

Результатом проходження офіцером навчання в системі ПВО має стати здатність ідентифікувати та осмислювати виклики, що становлять загрозу національним інтересам у сфері безпеки та оборони, на рівні вироблення внутрішньої та зовнішньої політики держави, розробки рекомендації та прийняття рішень (з пріоритетом на професійне воєнне бачення шляхів та можливостей розв'язання проблем); здатність управляти змінами, у тому числі в умовах підвищеного рівня ризику та невизначеності; здатність планувати та проводити спільні військові операції на стратегічному рівні, у тому числі глобальні інтегровані операції в умовах негативних змін; здатність стратегічно мислити й аналізувати кампанії, операції тощо.

У цілому розвиток професійних та лідерських якостей офіцера, як результат проходження навчання та підготовки в системі ПВО, має здійснюватись в універсалізованій системі вищої військової освіти та курсової професійної підготовки в межах розроблених та імплементованих у навчальний 
процес програм кожного ВВНЗ та ВНП ЗВО. Розробка відповідних програм має грунтуватися на організаційно-методичному забезпеченні, яке враховує особливості політик і процедур професіоналізації військової освіти за конкретними напрямами, а саме:

- визначення керівних положень 3 підвищення ефективності виконання та контролю за виконанням програм професіоналізації військової освіти (зорієнтованої на результати);

- розроблення методик оцінки ефективності реалізації програм професіоналізації військової освіти та визначення загальних положень щодо визначення результатів реалізації програм різних рівнів;

- розроблення пропозицій щодо структури програм професіоналізації військової освіти на всіх рівнях, їх цілей, змісту, типових форм;

- визначення можливостей поєднання програм військової та цивільної освіти на основі спільних цілей і сфер навчання;

- встановлення вимог до акредитації програм професіоналізації військової освіти;

- визначення вимог до звітності, у тому числі щодо акредитації та щорічної оцінки;

- визначення напрямів і шляхів нормативно-правового забезпечення професіоналізації військової освіти.

Фактично, професіоналізація військової освіти має здійснюватись шляхом модернізації системи базового і професійного навчання офіцерів протягом всієї кар'єри.

Висновки та перспективи подалыших наукових розвідок. Завдання щодо розвитку ПВО потребує перегляду концептуальних засад підготовки офіцерів тактичного, оперативного та стратегічного рівнів на основі імплементації ключових елементів відповідних концепцій країн-членів НАТО 3 урахуванням переорієнтації системи професійної підготовки офіцерських кадрів в Україні на спеціалізацію, інтенсивність та короткостроковість навчального процесу.

У перспективі розвитку системи ПВО та визначення шляхів удосконалення професійної підготовки офіцерів необхідним $\epsilon$ вирішення комплексу завдань, які потребують окремих досліджень, зокрема:

- розробка державного стандарту (Галузева рамка кваліфікацій) освітньо-професійної діяльності для галузі знань "Воєнні науки, національна безпека, безпека державного кордону" для кожного рівня підготовки за відповідною спеціалізацією згідно Національної рамки кваліфікацій та стандартів НАТО;

- оптимізація змісту освіти на основі включення до начальних модулів елементів практичної підготовки до професійної діяльності;

- удосконалення системи конкурсного відбору офіцерів на посади педагогічних, науково-педагогічних та наукових працівників 3 наданням пріоритету тим з них, які мають наукові ступені, вчені звання, досвід ведення бойових дій тощо; 
- поглиблення інтеграції військової освіти з бойовою та спеціальною підготовкою особового складу військ (сил), проведення з ним спільних заходів із залученням до цього інструкторів із держав-членів НАТО тощо.

\section{ЛІТЕРАТУРА}

1. Agbaria A. The "social soldier" and the mission to "retrieve the lost honor": An ideal image of the desired graduate of an Israeli general pre-military academy / Ayman Agbaria, Zach Shmueli // International Journal of Educational Development. - Vol. 66. - April 2019. - P. 88-95.

2. Augier M. Innovative Thinking: The Role of Professional Military Education / Mie Augier, Wayne Hughes // http://cimsec.org/innovative-thinking-the-role-of-professional-militaryeducation $/ 40280$.

3. Bonn K. Army Officer's Guide / Keith E. Bonn. - Harrisburg, PA: Stackpole, 1999.

4. Freidson E. Professionalism: The Third Logic / E. Freidson. - Chicago : University of Chicago Press, 2001.

5. Hersh M. Professional Ethics and Social Responsibility: Military Work and Peacebuilding / Marion Hersh // IFAC-PapersOnLine. - Vol. 50. - № 1. - July 2017. - P. 1059210602.

6. Johnson-Freese J. The Reform of Military Education: Twenty-Five Years Later / Joan Johnson-Freese // Orbis. A Journal of World Affairs. - Vol. 56. - № 1. - 2012. - P. 135-153.

7. Kelley K. Getting to the Goal in Professional Military Education / Kevin P. Kelley, Joan Johnson-Freese // Orbis. A Journal of World Affairs. - Vol. 58. - № 1. - Winter 2014. - P. 119132.

8. Kohn R. First Priorities in Military Professionalism / Richard H. Kohn // Orbis. A Journal of World Affairs. - Vol. 57. - № 3. - Summer 2013. - P. 380-389.

9. Professional Military Education A Cross-Cultural Survey / Ed. by Duraid Jalili and Hubert Annen. - Berlin, Bern, Bruxelles, New York, Oxford, Warszawa, Wien, 2019. - 234 p.

10. Snider D. Dissent and Strategic Leadership of the Military Professions / Don M. Snider // Orbis. A Journal of World Affairs. - Vol. 52. - № 2. - 2008. - P. 256-277.

11. The Canadian Forces Non-Commissioned Member in the 21st Century: Detailed Analysis and Strategy for Launching Implementation (NCM Corps 2020), August 2002. - 79 p.

12. U.S. Department of the Army. Pamphlet 600-3 Commissioned Officer Development and Career Management. - Washington, DC: U.S. Department of the Army, 1995.

13. Waggener A. Joint Professional Military Education. A Retrospective of the Skelton Panel / Waggener Anna T. // JFQ 77, 2nd Quarter 2015. - P. 55-59.

\section{РЕЗЮМЕ}

Дмитрий Витер, доктор философских наук, старший научный сотрудник Национальный университет обороны Украины имени Ивана Черняховского

Олег Митягин, кандидат исторических наук Национальный университет обороны Украины имени Ивана Черняховского

\section{Профессионализация военного образования в Украине: главные направления, содержание, перспективы}

Исследованы вопросы развития профессионального военного образования в Украине, определены основные направления, содержание и перспективы ее формирования с учетом опыта государств-членов НАТО в этой сфере. Предложена кониептуальная модель 
формирования абриса офицера будущего и структура курсовой профессиональной подготовки офицеров на тактическом, оперативном и стратегическом уровнях.

Ключевые слова: абрис офицера; военное образование; курсовая подготовка; лидерские курсы; НАТО; офицерские кадры; подготовка военных спеичалистов; профессиональное военное образование.

\section{SUMMARY}

Dmitry Viter,

Dr. (Philosophical sciences), senior researcher National Defense University of Ukraine named after Ivan Cherniakhovskyi

Oleh Mitiagin,

$\mathrm{PhD}$ (historical sciences)

National Defense University of Ukraine named after Ivan Cherniakhovskyi

\section{Professionalization of the military education in Ukraine: main trends, content, perspectives}

Introduction. Today is very important to develop the professional military education in Ukraine for higher of officer training effectiveness level, that connected with necessity to adopted the main tendencies of NATO' military education development.

Purpose. Define the main directs, content and perspectives of professional military education system forming in Ukraine in context of NATO' state-members in this sphere.

Methods. The system of general scientific and special methods of theoretical and empirical research (analysis of scientific literature, systematization and generalization of materials, logic and comparative, content analysis) was used in order to realize the article purpose.

Results. The article deals with the questions of professional military education in Ukraine, the main directs, content and perspectives of professional military education system forming in Ukraine in context of NATO' state-members in this sphere are considered. The conceptual model of future officer vision and a structure of professional training course' for officer at the tactical, operative and strategic levels are proposed.

Originality. Education and training of military specialists in the system of professional military education is considered as an integral and level-based system, which is compatible with system of NATO officers' training. Realization of main principles, which forming the future officer vision, can make in system of professional military education that orient to forming and development the officer-leaders in intellectual sphere, ensuring they achieve a high level of professionalism in theory and practice of art of war (operations), studying the methods, technologies and form of warfighting, make proposals for defense problems solving and using Armed Forces at high political level of public administration.

Conclusion. Tasks for development of professional military education need in revision of the conceptual bases for officers at tactical, operative and strategic levels training on the base of implementation the key elements the same system in NATO' state-members, and also change the orientation of officers staff training in Ukraine to specialization and intensity of education process.

Key words: coursing training; future officer vision; leading courses; military specialists training; NATO; officer staff; professional military education. 